Adres: Kadın Sorunları Araştırma ve Uygulama Merkezi, Cebeci 06590 Ankara

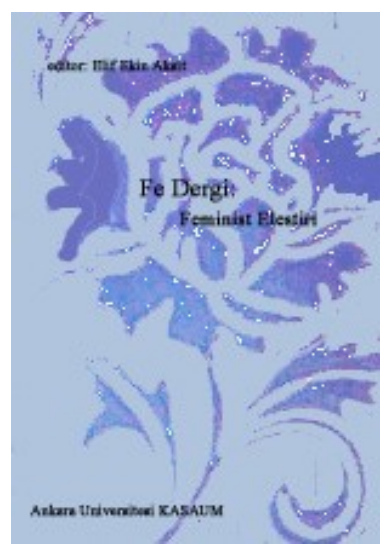

Fe Dergi: Feminist Eleştiri No. 1 Sayı 1

Erişim bilgileri, makale sunumu ve ayrıntılar için:

http://cins.ankara.edu.tr/

Köy Enstitüleri’nde kadın olmak

Semiha Tuna

Çevrimiçi yayına başlama tarihi: 27 Ağustos 2009

Bu makaleyi alıntılamak için: Semiha Tuna, “Köy Enstitüleri’nde kadın olmak,” Fe Dergi 1/1 (2009): 20-29.

DOI

URL: http://cins.ankara.edu.tr/tuna.html

$\mathrm{Bu}$ eser akademik faaliyetlerde ve referans verilerek kullanılabilir. Hiçbir şekilde izin alınmaksızın çoğaltılamaz. 


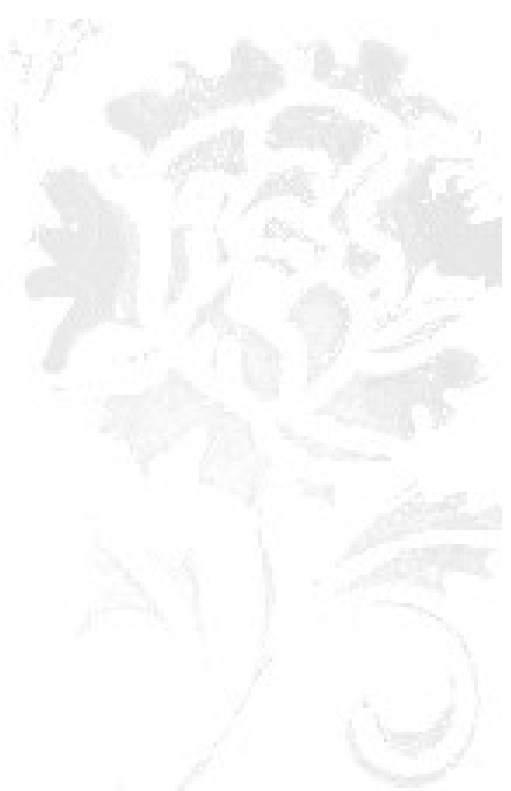




\title{
Köy Enstitüleri’nde kadın olmak
}

\author{
Semiha Tuna
}

\begin{abstract}
Kemalist ideolojinin sınırlarını çizdiği milliyetçi projenin temelini, ev ve aile oluşturmaktaydı. Kadınlar doğurganlık ve annelik rolleri ile gelecek kuşakların yetiştirilmesinde önemli bir rol oynayarak, Kemalist projenin taşıyıcısı haline indirgenmişlerdi. Kadınların eğitimi ise, hem milletin varlı̆̆ hem de gelecekte yetişecek vatandaşlar için temel önemdeydi. Bu bakımdan Köy Enstitüleri bir modernleşme pratiği olarak kadınların eğitimi açısından, bize farklı öngörüler sağlamaktadır. Köy Enstitüleri'nde kadınların en önemli görevi, köy kadınlarını yetiştirmek üzere belirlenmişti. Köy Enstitüleri’nde ĕ̆itim almış kadın ögretmenler köylere giderek, yeni bir ulusun inşası sürecinde köylü kadınların ve onların yetiştireceği vatandaşların eğitilmesine katkı sağlayacaklardı. Kadınların iş alanları daha çok kadınlık rolleri üzerinden şekillenmekteydi. Kadın ögretmenlerin köylere öğretmen olarak giderken alacakları demirbaş eşya, dikiş makineleriydi. Onların deneyimleriyle öğretmen olmanın dışında bir de meslek edinmişlerdi. Bu meslek daha çok köylerdeki kadınlara ve kızlara ögretilmesi gereken bir meslekti. Enstitülerin özellikle "iş içinde ĕgitim ilkesi”"ne göre temellendirdikleri ĕ̆itim politikası, kadınlar açısından eviçi işlerin bir devamı niteliğindedir.
\end{abstract}

\section{Being a Woman in the Village Institutes}

The nationalist project of Kemalist ideology was constructed in the house. Women were reduced to fertiliy and mother roles, and thus raising new generations. Education of women basicly important for the existence of the nation and for the citiziens who were going to be raised. As a modernist practice, Village Instutes provide us different foresights in terms of women education. Women's most important mission in the Village Institutes was the education of village women. Women teachers who had taken courses from the Institute went to the villages and in the construction process of a new nation, they contributed to the education of other women living in villages. Women's job opportunities mostly took shape from feminine roles. Women teachers' heavy fixture was sewing machine when they went to villages. Apart from being a teacher they had got a new job now. This was a job which has mostly to be taught to the women living in the village and their daughters. The education policy of Village Institutes which was mostly based on "the education at work principle" was the continuity of housework for women.

Köy Enstitüsü’nü bitiren bayan ögretmenin ideali, memleket kalkınmasının yanında halkı bilhassa köydeki kadının aydınlanmasını sağlayacaktı. ${ }^{1}$

Köy enstitülü kadınların anıları, bir iktidar edimi olarak biçimlenen tarih yazıcılığının kadınların tarihini anlatmaktan ne kadar uzakta biçimlendiğini göstermektedir. Türkiye'de Köy Enstitüleri tarihi, kadınların deneyimlerinin yer almadığı kadınsız bir tarih olarak şekillenmiştir. Köy Enstitüleri tarihiyle ilgili çalışmaların çoğunlukla erkekler tarafından yapılması ya da dillendirilmesi ve kadınların deneyimlerinin bu çalışmalarda yer almaması kanımızca bir eksikliktir. ${ }^{2}$ Bu eksikliğin giderilmesi için kadınların bakış açılarıyla ve deneyimlerinin de Köy Enstitüleri tarihinde yer alması gerektiğini düşünüyoruz. Buradan yola çıkarak amacımız, Köy Enstitüleri'ni kadınların bakış açısından yeniden değerlendirmektir. . Dolayısıyla bu çalışmada, tarihin kadınların deneyimleri ve bakış açılarına açılması için onların anılarının olası rolünden bahsedilecektir. . Araştırmanın önemi buradan kaynaklanmaktadır. Köy Enstitülü kadınların bu süreçte oynadığı tarihsel rolü kendi sözlerinden dinleyebilmek önemlidir. Böylece bu çalışma kadınların tarihsel özneler olarak tarih yapımına etkin katıldıklarını belgeleme imkanı sunmuş olacaktır.

Yapılan çalışmada, yöntem olarak sözlü tarih seçilmiş ve Köy Enstitüsü mezunu beş kadınla görüşme yapılmıştır. Bu görüşmeler birebir (yüzyüze) gerçekleştirilerek ses kaydına alınmıştır. Sözlü tarih, tek bir bireyin 
yaşamını ele alabildiği ve tarihsel olayların nasıl anlamlandırıldığı konusunda bize farklı bakış açıları sunabildiği için bir yöntem olarak seçilmiştir.

Araştırmada öncelikli belirlenen sorun, kadınların Köy Enstitüleri eğitim politikasını nasıl algıladığı ve nasıl deneyimlediğidir. Enstitü içindeki ilişkilerin nasıl gerçekleştiği, bu ilişkilerin kızlar tarafından demokratik bir ortam olarak mı algılandığı, bunun yanı sıra kadınların Köy Enstitüleri’nin yıkılışı hakkında neler düşündükleri ve Köy Enstitüleri'nin kadınsız bir tarihinin, onlar için ne ifade ettiği araştırmanın diğer problematiklerini oluşturmaktadır.

\section{Osmanlıdan Cumhuriyet'e Kızların Eğitimi: Kız Sanayi Mektepleri ve Kız Enstitüleri}

Türkiye'de yapılan kadın tarihi araştırmaları, hem Osmanlı dönemi kadınlarına, hem de Cumhuriyet dönemi kadınlarına ışık tutmuştur. Tarihin kadınlar açısından yeniden değerlendirilmesi görünmezlik problemini kısmen hafifletse de, yeniden yazılması için daha zaman vardır.

Osmanlı'dan Cumhuriyet'e Kız Sanayi Mektep'leri ve Kız Enstitüleri, kadınların toplumsal yaşamdaki konumları ve eğitimleri hakkında fikir sahibi olmak açısından birer örnek teşkil etmektedir. Bu eğitim kurumları bazı açılardan Köy Enstitüleri'yle benzerlikler göstermektedir. Bu benzerlikler özellikle toplumsal cinsiyet üzerinden tanımlanan rollerin eğitim politikasına yansımasında gözlenmektedir. Bundan dolayı Kız Sanayi Mektep'leri ve Kız Enstitüleri'ne değinmenin uygun olacağını düşüyoruz.

Elif Ekin Akşit'in çalışmasından yola çıkarak 19. yy. Osmanlı'da kız çocuklarına yönelik öne çıkan eğitim kurumlarından şu şekilde bahsetmek mümkündür: 1850’lerde açılan Kız Rüştiyelerini takiben, 1865 yılında kurulan Kız Sanayi Mektepleri, o zamana kadar sarayda ve kimi seçkin evlerde süren eğitim biçimlerini örnek almıştır. Kız Sanayi Mekteplerin'de ev içi eğitim ve saray eğitimi pratiklerinin kamusal alana taşınmasıyla birlikte, modern devlet olma yolundaki Osmanlı'nın etkisiyle okulların hedefleri arasında, öncelikle kızları sanayiye hazırlamak gelmektedir. İş ve eğitimin bir arada olduğu okullarda elişi üretimi ve dersi, eğitimin temelini oluştururken; diksiyon, tarih, çizim vb. dersler sanayiye yönelmeyecek olan kızların genel bir eğitim almasını da içermektedir. Kız eğitim kurumları olarak Kız Sanayi Mektepleri modernleşen devletin, devlet eğitimi ile ev içi eğitim arasında bağlantı kurarak, alt sınıftan kızların eğitilmesi projesinin yanı sıra, aynı zamanda kadınların hayatlarını şehir içinde düzenlemesi ve denetlenmesi açısından bir pratik olarak değerlendirilebilir. ${ }^{3}$

Osmanlı modernleşmesine öncülük edecek yapısal değişimler özellikle II. Meşrutiyet döneminde gündeme gelmiş, bu yıllarda toplumsal yaşam her yönüyle değişmeye başlamıştır. Bu değişimi kadının konumunda da gözlemek mümkündür. Osmanlı toplumunda Tanzimat sonrasında yaşanan değişimler kadınlar açısından bir yandan eşitlik yönünde önemli adımlara yol açsa da, diğer yandan eşitliğin çerçevesinin devlet tarafından yeniden çizilmesine yol açmıştır. Türk modernleşmesinde kadınlara Batılılaşma ve modernleşmenin taşıyıcılığı rolü verilirken, bu rolün sınırları erkekler tarafından belirlenmiştir. Eğitilmiş kadınların ailenin ve ulusun daha iyi ve erdemli anneleri olacakları tezi, Osmanlı toplumundaki en güçlü ifadesini 19. yüzyılın sonlarıyla 20. yüzyılın başlarında bulacaktır. Osmanlı kadınları ve onları hem destekleyip hem de söylemin ve pratiğin sınırlarını çizen erkek aydınlar, kadın eğitimin gerekliliğini Batı'daki tartışmalara benzer biçimde kadının eş ve annelik rolünü daha iyi yapabilmesi üzerinden temellendirmektedirler. ${ }^{4}$

Cumhuriyet kurulduktan sonra kadınların eğitimi, yeniden şekillenen milli söylemin bir parçası olmuştur. “Cumhuriyet Kızı" söylemiyle birlikte öne çıkan vurgu, Kız Enstitüleri'nin kuruluşu (1929) ile milliyetçi politikaların üretildiği bir mekan halini almaktadır. İnönü siyasetinin bir parçası olan Kız Enstitüleri, bir bakıma yeni kurulan bir ulusun kültürel sembolleridir. ${ }^{5}$

1865 yılında kurulan Kız Sanayi Mektepleri'nde kızların eğitimi, kadınlara ev idealinin benimsetildiği, modernleşen devletin sanayi ihtiyaçlarını gidermeye yönelik bir devlet eğitimi şeklindedir. Modernleşmenin iki yüzü olan Kız Sanayi Mektepleri ve Kız Enstitüleri arasında üretim odaklı eğitim konusunda bir devamlılık vardır. Ev ideali olarak kadınlara sunulan ideolojik üretimdeki vurgu, Kız Enstitüleri için belirgin bir yer edinmektedir. "Cumhuriyet Kızı" söylemiyle birlikte milliyetçi politikaların üretildiği bir mekan halini alan Kız Enstütileri'nde kızlar, ev idaresinin temel olarak alındığı bir eğitim politikasından geçirilmektedirler. ${ }^{6} \mathrm{~K}_{1 z}$ Sanayi Mektepleri'nin zaten azalmış olan sanayi vurgusundan uzaklaşılmış, ideolojik üretime daha fazla ağırlık verilmiştir. Bu tip bir eğitimin ürünü olacak Türk Kızı'nın yeri okuldan mezun olunca, evi olarak belirlenmiştir. 1929'daki iktisadi daralmaya paralel olarak, yeniden düzenleme neticesinde kadınlar, nadiren de olsa ücretli olarak çalıştıkları yerlerden evlerine dönmeye özendirilmişlerdir. Yani ilk kuşak Cumhuriyet Kızlarının eğitiminde önemli olan onlara iş bulmak değil, cumhuriyetin yeni ideolojisini benimsetmek, mümkün olduğu kadar yaymak ve yeni kuşakları bu doğrultuda yetiştirmektir. ${ }^{7}$ 
Tek partili dönemde Kız Enstitüleri normal liselere dönüşürken, Köy Enstitü’lerin açılması yeni bir eğitim anlayışının ortaya çıkmasını sağlayacaktır. Kız- erkek öğrencilerin birlikte eğitim göreceği bu yeni eğitim anlayışının bir ürünü olan Köy Enstitüleri, 1950 yılında çeşitli suçlamalarla yıkılma sürecine girecektir.

\section{Köy Enstitüleri ve Kadınlar}

1940 yılında kurulan Köy Enstitüleri, eğitim politikası bakımından Kız Sanayi Mektepleri ve Kız Enstitüleriyle pratiğe yön veren milliyetçi eğitim politikaları bakımından benzerlikler taşımaktadır. Köy Enstitüleri’nin amacını oluşturan köyü ve köylüyü kalkındırma ideali, bir bakıma cinsiyete dayalı iş bölümüyle şekillenmektedir. Köy Enstitüleri’nde kızların eğitimi, yeni bir ulusun inşası sürecinde köylü kadınların ve onların yetiştireceği vatandaşların eğitilmesini hedeflemektedir. . Milliyetçi söylemde kızlar için modern $r$ eğitimin gerekçesi, aydın annelik ve çocuk yetiştirme üzerinden tanımlanmaktadır. Buna bağlı olarak, Enstitü’lü kızlar için köylünün kalkınma ideali, köylü kadınların eğitimine bağlanmaktadır. . Aynı zamanda, Enstitü'lerde erkek öğrencilere verilen iş teknik dersleri -modern tarım araçlarının ve aletlerinin kullanımı- bir bakıma köyün ekonomik kalkınma idealini erkeklere yüklemiş gibi görünmektedir.

Modern bir eğitim kurumu olarak tasarlanan Köy Enstitüleri’nde kızların aldıkları eğitim, toplumsal cinsiyet rollerine göre belirlenmektedir. Enstitülerin özellikle "iş içinde eğitim ilkesi”ne göre temellenen eğitim politikası, kızlar açısından eviçi işlerin bir devamı niteliğindedir. Öğretmen olarak yetiştirilen kız öğrenciler, köylere gittiklerinde öğrencilere verdikleri öğretim dışında, köylü kadınlarına modern ev kadının nasıl olması gereklerini öğreteceklerdir. Bu işler arasında en öne çıkan dikiş makinesi ile dikiş dikmektir. Öğretmenlik dışında dikiş dikmek sanki Enstitülü kızlar için bir meslek olarak belirlenmiştir.

Türkiye'de yatılı düzeyde karma eğitim, ilk kez Köy Enstitüleri’nde uygulanabilmiştir. 1945-46 ders yılı verilerine göre, enstitüdeki 14.464 öğrenciden 1396'sı kız öğrencidir. ${ }^{8}$ Bu dönemde Köy Enstitü’lerine alınan kız öğrenci sayısı az olmakla birlikte, karma eğitim meselesine özellikle önem verilmiştir.

Köy Enstitü’lerine kız öğrenci bulmakta yaşanan zorlukların, bazı nedenleri vardır. Öncelikle, ilkokulu bitiren kız öğrenci sayısı az olmakla birlikte, bu dönemde köylüler kızlarını bu okullara gönderme konusuna kuşkuyla yaklaşmaktadırlar. Köy Enstitülü kadınlarla yapılan görüşmelerde, köy okullarının hem yatılı olması, hem de uzak yerlerde kurulmuş olmaları nedeniyle ailelerin kızlarını bu okullara göndermek istemedikleri bilgisine ulaşılmıştır. Özellikle köylerde yaşanan cinsiyete dayalı işbölümü ve buna bağlı olarak kızların hem evle ilgili sorumlulukları hem de üretime yönelik (tarla ya da bahçede yapılan işler) büyük katkıları vardır. Bunun yanı sıra, kız öğrencilere yönelik geleneksel ataerkil baskılar ve çevrenin bu konudaki tutumu kızların eğitim hayatını etkileyen temel belirleyicilerdir.

$\mathrm{Bu}$ sorunlara karşın okulun ilk açıldığı dönemlerde, kızları Enstitü’ye kaydetmek amacıyla köyler gezilerek, aileler ikna edilmeye çalışılmıştır. Kızları Enstitü’ye alma konusunda pozitif bir ayrımcılıktan söz edilebilir. Erkek öğrenciler kız öğrencilerle birlikte kayıt yaptırırsa, erkek öğrenciler sınavsız bir şekilde Enstitülere alınmaktadır ${ }^{9}$. Ayrıca, Enstitü eğitimine katılımları çok az olan kız öğrenciler sınavsız olarak okullara alınmıştır.

Köy Enstitüleri’ne gönderilme, her Enstitülü kız için ataerkil baskılara karşı bir sessizliği ya da bir direnişi ifade etmektedir. Bu anlatılar Köy Enstitüleri'nde kız öğrenci sayılarının az olmasıyla başlamakta ve Köy Enstitüleri'nde okumak için hevesli kızların hikayesi bir tedirginlik içinde Enstitü'lerde sonlanmaktadır.

\section{Enstitü'ye Gönderilme}

Tasarladı̆̆ım gibi bir okulla karşılaşmadım. Yatılı okula gidiyorsun bir pijama giyeceksin, terlik giyeceksin, çocukluk işte. Onlar benim hoşuma gidiyordu. İşte arkadaşlarım olacak.. Gittik ki ögrencileri göremedim. Onlar da çalışıyormuş iş elbisesiyle, ben onları işçi sanıyorum.. Kızlar hiç çıkmıyor odadan. Evde ev hanımları nasıl oturuyor bizde öyle oturuyoruz. Birde azdı ögrenciler okullar yok ki ögrenci versin, çok zor bulunuyordu. ${ }^{10}$

Kızların Enstitü’ye gönderilme hikayeleri, erkek egemen söylem tarafindan şekillenmektedir. "Kızlar hiç okula gönderilir mi!” sözleriyle başlayan engeller, öğretmenlerin aileleri ikna etmesiyle aşılmaya çalışılmaktadır. Kızlardan birisi ancak abisiyle Enstitü’ye gidebilirken'; bir diğeri, yakın akrabasının erkek çocuğu okula kaydedilebilsin diye"11, Enstitü'ye gönderilmektedir. "Ĕ̆ger enstitüler açılmasaydl, benim okuma şansım yoktu; babam Atatürk döneminin ögretmenlerinden olduğu halde" ${ }^{12}$ diye söze başlayan Perihan Gürler ise, okula

\footnotetext{
${ }^{1}$ Ankara, Meliha Sürücü, (25.04.2008)
} 
gönderilme hikayesini, hem Enstitülerin açılmasına hem de babasına borçlu olduğunu dile getirmektedir. Halise Apaydın ise, öğretmen olabilmek için babasına ve annesine karşı bir mücadeleye girişmektedir. "Ben slkılgan bir çocuktum.... sıkılgan olduğum halde böyle karşı çıktım, sonunda babam dayanamadı." s3 sözleri öğretmenlerin ve kasabanın ileri gelenlerinin iknasıyla okul yolculuğuna başlamaktadır. Emine Biçer ise, 194445 yılları arasında Hasanoğlan Köy Enstitü’süne sınavla alınmıştır. Sözlü sınavda genel kültür niteliğinde tarih, matematik vb. gibi sorular sorulmuştur. Bu dönemde kız sayısı oldukça artmıştır. "40 kızlar" olarak hatırladığı sınıfına, kendi köyünden de birçok kız öğrenci kaydolmuştur.

Enstitülü kızlar, Köy Enstitüleri’nin kurulmasının, özellikle kızların okula gönderilmesi açısından çok önemli olduğunu düşünmektedir. Bu dönemde Enstitülere gidebilmeleri, onlar açısından bir çeşit mucize gibidir. Köy Enstitüleri'nin köydeki öğrencilerin okuyabilecek bölgelerde kuruluşu, özellikle köylü kızların okutulabilmesi açısından önemlidir.

Köy Enstitüleri’nde kız öğrenci sayıları bölgelere ve tarihlere göre değişmektedir. Görüşme yaptığımız kadınların sınıflarındaki kız öğrenci sayıları şu şekildedir: Çifteler Köy Enstitüsü’nde 1940'larda 21 kız; İvriz Köy Enstitüsü'nde 1945'lerde 4 kız; C1lavuz Köy Enstitüsü’nde 1940'larda 7-8 kı; Hasanoğlan Köy Enstitüsü'nde 1941'lerde 3 kız; 1944'lerde ise, 40 kız öğrenci 20'şer iki sınıfa dağıtılmıştır.

Genel olarak baktığımızda kız öğrenci sayıları oldukça düşüktür. Okulun ilk açıldığı yıllarda Çifteler Köy Enstitüsü'nde kız sayısı diğerlerine oranla fazladır. Enstitü'nün eğitmen kurslarından kalan bir okul olması ve eğitime hemen başlaması bu konuda etkili olmuş olabilir. Bölgesel farklılıklar da bu konuda etkili olabilmektedir. Örneğin İvriz Köy Enstitüsü’nde 1945'ler olmasına rağmen kız öğrenci sayısı hala 4'tür. Köy Enstitüleri'nin örnek okulu haline gelen Hasanoğlan Köy Enstitüsü ise, 1944'lere doğru kız öğrenci sayıs1 artmaktadır.

Enstitü’ye ilk yıllarda giren kızlar, başlangıçta sert bir tutum içinde olan köylülerin zamanla Enstitü’leri daha olumlu algılandığını ve kızlarını okula göndermeye başladıklarını aktardılar. Enstitü'lü kadınlardan okul birincisi olan Ayşe Baysal, köylü kızların okula gönderilmesinde ön ayak olduğunu düşünmektedir. ${ }^{14}$ Enstitü'deki başarılarının köylüler tarafından da takdir edilmesiyle birlikte, köylülerin kızlarını okula gönderme konusuna daha olumlu yaklaştığını düşünmektedir. Ayşe Baysal aynı zamanda köylülerin Enstitüye olan olumlu yaklaşımını, kızların ekonomik bir değer olan öğretmenlik mesleğini yapmalarına ve eve para getirmelerine bağlamaktadır.

Kızların Enstitü’ye ilk gidişleri yeni bir yolcuğun hikayesi kadar uzundur. Bazı kızlar yürüyerek bazıları ise, hiç tanımadıkları insanlarla birlikte at arabasında yolculuklarını tamamlamışlardır. Enstitülü kızların anılarına baktığımızda, Enstitü'ye ilk geliş bir "alışamama" ya da "garipseme" durumudur. Bu durum okuldan kaçma isteğine bile neden olabilmektedir. ${ }^{15}$ Enstitülerin klasik okullardan farklı oluşu ve iş içinde eğitim ilkesi, öğrencilerin başlangıçta okul ortamına alışmalarını zorlaştırmıştır.

Ayşe Baysal Enstitü ortamını, kendi çevresinden insanların olduğu bir yer olarak tanımlamıştır. Çevresinde tanıdık insanların varlığı onun Enstitü’ye daha çabuk alışmasına yardımcı olmuştur. Perihan Gürler ise Enstitü ortamını okulla velilerin kaynaştığı bir yer olarak tanımlamıştır. Velilerin sık sık öğrencileri ziyaret edebileceğini ve isterlerse okulun misafirhanesinde kalabileceklerini aktarmıştır. Genel olarak değerlendirdiğimizde, Enstitü’ye alışma evresi tamamlandığında, artık Enstitü’ler kızlar için vazgeçilmez bir yer haline gelmektedir. "Alıştıktan sonra çok sevdim "16 sözleri Enstitülü kızların ortak düşünceleridir.

\section{B. Enstitü Ortamı ve Kızların Ĕ̈itimi}

“Günde 30 tane nevresim diktiğimi bilirim. Pratiğim o kadar kuvvetliydi.",17

Köy Enstitü’leri, birçok birimleri ve iş alanları olan eğitim işletmeleri olarak kurulmuştur. Ders ve çalışmanın yarısının tarım ve tekniğe yönelik olması yasayla saptanmıştır. Yasaya göre yarısı teknik ve tarım dersi ve çalışmaları, diğer yarısı kültür derslerine ayrılmaktadır. Yani, derslere verilen toplam sürenin yüzde 50'si genel kültür ve meslek dersleri, yüzde 25'i iş (teknik), yüzde 25’i ise tarım ders ve çalışmalarına ayrılmıştır. Enstitü'de gerçekleştirilen iş eğitimi aynı zamanda köyde yapılan kadın erkek etkinliklerin bir devamı niteliğinde olduğunu söyleyebiliriz. Örneğin; köylerdeki iş hayatında, kadınların "ağır” işler olarak nitelendirdikleri harman savurma, saban sürme gibi işleri daha çok erkekler yapmaktadır ${ }^{18}$. Kadınların yaptıkları işler, daha çok bahçelerde çalışma, ürünleri toplama, yük taşıma gibi işleri içermektedir.

Özellikle Enstitülü kızların ziraat sanatları derslerinde yaptıkları işler şu şekilde belirlenmiştir: Tavukçuluk, bahçe ve meyvecilik, arıcılık, çiçekcilik, tahıldan, sebze ve meyvelerden türlü usullerle kışlık yiyecek hazırlama, etleri muhafaza usulleri, ehli hayvan bakımı, konserve aletleriyle sebze ve meyveleri 
muhafaza etme usulleri, yoğurt, beyaz peynir yapma, yağ çıkarma ve bunları muhafaza etme vb. gibi etkinliklerdir. ${ }^{19}$

Ziraat ders ve çalışmalarında; Tarla Ziraati, Bahçe Ziraati, Sanayi Bitkileri Ziraati ve Ziraat Sanatları, Zooteknik, Kümes Hayvancılığı, Arıcılık, ve İpek Böcekciliği, Balıkçılık ve Su Mahsulleri vardır. Bu çalışmalar okullara ve okulların bulunduğu koşullara göre şekillenmektedir. Bu dersleri kız ve erkek öğrenciler birlikte almaktadır. Ancak 1943 Köy Enstitüleri Öğretim Programı'na göre, “yalnız ziraat çalışmalarında kız-erkek talebenin özelliklerine göre konular seçilir" denilmektedir. ${ }^{20}$ Fakat yapılan görüşmelerde bu derslerde yapılan etkinliklerin içeriğinin, toplumsal cinsiyete göre şekillendiğini gözlemleyebiliyoruz. Örneğin, Ziraat derslerinde sebze bahçesinde kız öğrenciler çalışmaktadır. Bellemeyi kadınlar, çift sürmeyi ise, erkekler yapmaktadır. ${ }^{21}$ Ekin toplama, hayvan besleme ve sağma daha çok kıların yaptığı işlerdir. ${ }^{22} \mathrm{~K}$ ız öğrenciler okulun eriştesini, tarhanasını yapmaktadır. ${ }^{23}$ Genellikle beden gücüyle ilgili olduğu düşünülen bu derslerde, kızlar daha çok "hafif" olarak nitelendirilen işlerle uğraşmaktadırlar. ${ }^{24}$ Görüşmeden elde ettiğimiz sonuçlara göre; sebze bahçesinde çalışma, yumurta toplama, hayvan besleme, süt sağma işlerini daha çok kız öğrenciler yapmaktadır.

Enstitü’ye ait hayvanların sütünden yoğurt ve peynir yapma, turşu, konserve yapma, kışlik yiyecekler hazırlama vb. kızların etkinlik alanlarıdır. Tavukçuluk, meyvecilik, arıcılık, evcil hayvan bakımı gibi işler kız öğrencilerinin aldığı dersler ve çalışmalardır. Yaptığımız görüşmelerde kızların yaptığı etkinlik alanları şu şekilde tanımlanmıştır: Okulun eriştesini ve tarhanasını yapmak, hayvan besleme, süt sağma, peynir ve yoğurt yapma, ekin toplama, toprak belleme, turşu kurma, budama, saklama, ispanak dikme, yumurta toplama vb. işlerdir. Bu ders kızlar ve erkekler tarafından birlikte alınmasına rağmen, bu derslerde toplumsal cinsiyete dayalı bir işbölümüne rastlamaktayız. Genellikle beden gücüyle ilgili olduğu düşünülen bu derslerde, kızlar daha çok "hafif" olarak nitelendirilen işlerle uğraşmaktadırlar. Bu ayrım Enstitülü kızlar tarafından şu şekilde dile getilmektedir; "A "̆ı̆ işleri erkekler yapıyordu. Hafif işleri kızlar yapardı. Biz sebze bahçesinde çalıştık. Çift sürmeyi erkekler yapıyordu." 25 "Krizma ${ }^{26}$ kazmayl erkekler yapıyordu. Arıcılık işini de erkekler yaparlardı. Kızlar yumurta toplama işini yaparlardı."27 "Hayvan besleme, sağma işlerini daha çok kızlar yapıyordu." 28 "Sürme pulluk kullanma erkeklerin, kenarları kazma kızların işiydi. "29

Enstitülerin birinci sınıflarındaki kız öğrencilere gösterilecek teknik dersler ve çalışmalar şu şekilde belirlenmiştir: Köy ev ve el sanatları (el ve makine dikişleri, iplik yapma, örme, dokuma nakış vb.), makine ve motor kullanmadır. ${ }^{2}$ Makine ve motor kullanma dersi ise; dikiş ve çorap makinelerinde çalışma, bisiklet kullanma, krema makinesinde çalışma ve yayıklarda çalışma olarak açıklanmaktadır. ${ }^{30}$

Kız öğrencilere teknik ders ve çalıșmalarında; ikinci, üçüncü, dördüncü ve beşinci sınıflarda dikiş, örgü ve dokuma, ziraat sanatları verilmektedir. Dikiş ve biçki derslerinde; iş elbiseleri biçme, bedenden ölçü alma, patron çıkarma, yatak takımı, çamaşır gömlek ve önlük biçme vb. gibi etkinliklerdir. Örgü ve dokuma derslerinde; çorap makinesinde çalışma, kilim ve halı dokuma, el dokumaları yapma vb. gibi etkinlikler yer almaktadır. ${ }^{3}$ Görüşmelerden elde ettiğimiz sonuçlara göre; toplumsal cinsiyete göre belirlenen bu etkinlik alanlarında, kız öğrenciler Enstitülerin gereksinimlerine yönelik giysi, çarşaf, çamaşır gibi ihtiyaçları diker, ${ }^{4}$ elbiseleri tamir eder, ${ }^{31}$ bunun yanı sıra gereksinimlere yönelik kilim, halı, tülbent, gömleklik bezlerin dokunması, eldiven, atkı çorap vb örülmesi gibi faaliyetler de yapılmaktadır.

Toplumsal cinsiyet rollerinin öğrenilmesi bir bakıma eğitimin temel politikasıdır. Cinsiyete dayalı bu roller, kız öğrencilerin etkinlik alanlarında kendini göstermektedir. Eğitim politikası erkek ve kızların aldığı ortak genel kültür derslerini içermekle birlikte, Enstitü'nün temel aldığı iş dersleri cinsiyetlendirilmiş bir biçimdedir. Özellikle bu temel ayrımı yüksek kısımdaki alanlar da gözlemlenmektedir. Yüksek Köy Enstitüleri'nde $^{32}$ cinsiyete göre ayrılan bölümler Enstitülerde verilen eğitim politikasının bir devamı niteliğindedir. "Kümes Hayvancılığı Kolu” ve "Köy Ev İşleri” ve "El Sanatları Kolu” sadece kızlara yönelik açılan bölümlerdir. Kümes Hayvancılığı Kolu'nda kızların aldığı dersler; kümes hayvanları bakımı, çocuk bakımı, yemek pişirme, biçki-dikiş gibi derslerdir. Köy ev işleri ve el sanatları kolunda ise, besin ve doku maddeleri kimyası, çocuk bakımı, biçki-dikiş, nakış, dokuma, örücülük gibi dersler bulunmaktadır. "Maden

\footnotetext{
${ }^{2}$ Köy Enstitüleri ve Çağdaş Eğitim Vakfı (2004) Köy Enstitüleri Programı, Köy Enstitüleri ve Çağdaş Eğitim Vakfi Yayınları, Ankara, s. 112

${ }^{3}$ Köy Enstitüleri ve Çağdaş Eğitim Vakfi (2004) Köy Enstitüleri Programı, s. 233-240

${ }^{4}$ Ankara, Halise Apaydın, (26.02.2008 ve 04.03.2008)
} 
İşleri Kolu", "Hayvan Bakımı Kolu" ve "Tarla ve Bahçe Ziraati Kolu" sadece erkek öğrencilerin alınabildiği bölümlerdir. "Güzel Sanatlar Kolu" ve "Zirai İşletme Kolu" ise, her iki toplumsal cinsiyetin girebildiği bölümler olarak açılmışlardır.

Erkeklerin iş teknik derslerinde aldıkları; demircilik ve nalbantlık, dülgerlik ve marangozluk, yapıcılık, makine ve motor kullanma alanları ve bu derslerde yaptıkları ziraat makinelerini sökme, temizlemek, yağlama, basit tamirleri yapma, işliklerdeki makine ve motorları kullanma, değirmen, kamyon, elektrik, motor ve tesisatı işlerinde, balya makinelerinde çalışmak vb. gibi etkinlikler bize göstermektedir ki, modern teknik ve işlerin erkek öğrenciler tarafından kullanılmasına yöneliktir. Bu verilere göre, Köy Enstitüleri'nin köyü ve köylüyü kalkındırma ve geliştirme amacı, esas olarak erkek öğrencilere yüklenmektedir. Köylünün zirai ve ekonomik ihtiyaçlarını giderme yönünde eğitim verme ve bunları temin etme görevleri erkek öğrencilere verilmiştir. Buna bağlı olarak Köy Enstitüleri Kanunu'nda belirtilmesine rağmen, ${ }^{33}$ Köy Enstitüleri'nin kadın ve erkek eşitliği idealini pratik olarak yerine getiremediğini söyleyebiliriz.

Enstitüler arası yardımlarda bu ayrıma tekrar rastlamaktayız. Görüşmelerden elde ettiğimiz bilgilere göre, kızlar genellikle bu işlerde kum ya da taş taşıyarak erkeklere yardım etmektedirler. Bunun yanı sıra inşaatın temizlik islerini yapmaktadırlar. ${ }^{34}$

Öğrenciler Enstitü'den mezun olduktan sonra, öğretmen olarak gittikleri köylerde yirmi sene zorunlu hizmet yapacaklardır. Enstitüleri'nden verilen malzemelerle hem köylüyü hem de köylü çocuklarını aldıkları eğitimle birlikte eğitecek, öğrendiklerini köy yaşamına uygulayacaktır. Enstitülü kızlar açısından köylülerin eğitimi köylü kadınların eğitilmesi anlamına gelmektedir. Köylü kadınların eğitimi bir bakıma, kadınların eviçi rolleriyle birlikte tanımlanmaktır.

Enstitülü kızlar mezun olduklarında, köylere öğretmen olarak gittiklerinde dikiş makinesi Enstitü tarafından verilmektedir. Dikiş makineleri gittikleri okulların demirbaş eşyaları sayılmaktadır. Kadın öğretmenler dikiş makineleriyle köylülerin ihtiyaçlarını dikmekte ya da köy kızlarına dikiş dikmesini öğretmektedir. Hatta bu konuda köylerde kurslar bile açabilmektedirler. Meliha Sürücü bize bu konudaki deneyimlerini şöyle aktarmaktadır. "Dikiş makinesi aldım. İşime yaradl. Köylülerin işlerini diktik. İlk gittiğim yerde kaldı demirbaş. Dikiş kursu diğer okulda açtım. Dikiş makinesini; mesleğimiz için verdiler, öğretmenliğin yaninda terzi oldum ",35

Enstitülü kızlar okulda yapılan etkinlikleri yorucu ve zor olarak nitelendirmediler. "Hiç de ağır değildi. Köyde yaptığımızdan daha kolaydı. Biz zaten köyde o işleri yapıyorduk." "Ben hiç hatırlamıyorum. Hatta ben bluğ çağl diye bişsey geçirmedim. O kadar meşguldük ki; mesala mandolin çalar, kitap okur dikiş dikerdik. Zamanımız çok doluydu ve bundan şikayetçi değildik." " ${ }^{36}$ Halise Apaydın'a göre ise; Enstitülerdeki yaşam şartlarına alışabilmek kişiye göre değişmektedir. "Kişinin azmine göre değişiyordu.. Geriye dönmek isteyenler oldu. Klasik okullar olmadı̆̆ için zor oldu. Özellikle şehirden gelenler kesin döndüler. ${ }^{\prime 37}$ Enstitü hayatı herşeye rağmen zor ve dolu geçse de, kadınlar genellikle bu konudan şikayetçi değillerdir. Enstitü'de yaptıkları işleri zaten kendi köylerinde yaptıklarını dile getirdiler.

Kadınlar derslerin hepsini sevdiklerini söylemelerine karşın kültür dersleri ile daha ilgili olduklarını belirtmişlerdir. Halise Apaydın tarih dersini, Emine Biçer eğitim derslerini en sevdiği ders olarak nitendirmekte, Ayşe Baysal ise, matematikte daha başarılı olduğunu aktarmıştır. Meliha Sürücü ve Perihan Gürler bütün dersleri sevmektedir.

\section{C.Karma Ĕ̈itim ve Düşündürdükleri}

"Bir sürü iftiralar atıllyor, işte kızlar çocuk düşürdü. Halbuki öyle birşey yok. Köy ağaları, milletvekilleri yandaşları böyle dedikodular çıkarıyorlar. Karma eğitimi hiç yadırgamadık biz. Köylerde tarımda, kadın erkek birlikte çalışırlar. ${ }^{38}$

Görüşme yaptığımız Enstitülü kızlar Enstitü'yü demokratik bir ortam olarak tanımladılar. Enstitülerin demokratik olma özelliğini, Enstitüdeki işlerin ortak bir şekilde yapılması ve bu işlerin eleştiriye açık olması, hatta öğretmenlerin bile eleştirilebileceği bir ortam olarak nitelendirerek açıkladılar.

Enstitü’lerdeki öğrenciler arası ilişkiler abi-abla, kardeş ilișkileri șeklinde tanımlanmaktadır. "Kocamla oradan tanıdık evlendik. Kardeşçe beş sene orada yaşadık ve çok güzel şeyler öğrendik." "39 "Amcamın dayımın çocuğu gibi düşünüyordum herhalde. İlişkilerimiz köyden getirdiğimiz alışkanlıklarımızın bir devamıydl... kardeşim gibilerdi. ${ }^{, 40}$ Enstitüde kızlar ve erkekler arası mesafeler kardeș söylemiyle kurulmaktadır. Öğrenciler kendi denetimlerini kurdukları sürece herhangi bir sorun yoktur. Enstitü’nün kız erkek ilişkileri üzerinde

${ }^{5}$ Ankara, Ayşe Baysal, (21.03.2008 ve 07.04.2008). 
kurduğu denetime dair bazı anlatılar bulunmaktadır. Emine Biçer okulda öğretmenler tarafından uygulanan baskılardan şu şekilde söz etmektedir.

Ë̆itim başımız bayanlar için baskı kurmaya çalışırdı. Nedir bu saçınız diye şuradan kesip de erkek traşı gibi götürdüğünü bilirim. Güzel kızları kıskanma huyu vardl. Birazda psikoloji hocamız vardı. O da baskı kurmak isterdi. Saçımızla uğraşırdı. Kızla erkek ayrımı yapardı. Baskılıydı. Diğer hocalarımız hiç kız ve erkek arasında baskı kurmazdı. ${ }^{41}$

Enstitülü kızlar genellikle, Enstitü içindeki ilişkileri gayet samimi bir ortam olarak nitelendirdiler. "Hiç bir bask yoktu." "Çok yakın ilişki kurardık",2 "Öğretmenler bize öğrenci demezlerdi. Daha çok arkadaşım derlerdi." " ${ }^{43}$ Emine Biçer'in Enstitü'deki ilişkilerin biraz sınırlı olduğundan söz etti. "Biraz sınırlıydı çok samimi diyemem. Öğretmenlerden çekinirdik. Herşeyimizi soramazdık. Sınıf öğretmenlerimize sorardık daha çok ona anlatırdık." ${ }^{4}$ Emine Biçer'in Enstitü ortamının bu şekilde sınırlı bir şekilde biçimlemesini, 1947'den sonra yapılan değişimlerin etkili olabileceğini belirtmektedir.

Enstitü'deki öğrenciler arası denetim daha çok kız erkek ilişkilerinde ortaya çıkmaktadır. "Denetim çok fazlaydl. Klz erkek arası uygunsuz olmasın diye. "45 Ayşe Baysal ve Emine Biçer'in Enstitü’nün kız erkek öğrenciler üzerindeki denetimi hakkında aktardıklarını, Enstitü politikasının 1947'de özgün yapısından uzaklaşmasıyla ilişkilendirebiliriz. Bu dönemde muhafakar tepkilerle birlikte karma eğitim suçlamalarına maruz kalan Köy Enstitüleri, 1950’de kız ve erkek öğrencilerin farklı okullarda toplanmasına yol açmıştır.

Halise Apaydın ise, bu denetimi kendi içinde hissetmesine rağmen, kız erkek ilişkileri üzerine bir sorun yaşanmadığını dile getirmiştir. Özellikle Halise Apaydın Hasanoğlan Yüksek Köy Enstitüsü’ndeki kız erkek ilişkilerinde eğitim ortamının özgür olarak şekillendiğini düşünmektedir. Meliha Sürücü ve Perihan Gürler bu konuda herhangi bir denetimin olmadığını dile getirmişlerdir.

Enstitü'lerdeki eğitim politikası aynı zamanda, Enstitü ortamın nasıl şekillendiği ile ilgilidir. Bu durum hem Enstitü'lerin bulunduğu bölgeden hem de Enstitü’lerin eğitimini sağlamaya çalışan müdür ve öğretmenlerin tutumundan da etkilenmektedir. Genel olarak baktımızda, Enstitü'nün teorik çerçevesinin dışında pratik olarak nasıl işlediği de bu açıdan önem kazanmaktadır.

Kız öğrencilerin "kadınlık” rollerine dair söylemler, kimi derslerde Enstitülü öğretmenlerin sözlerinden az da olsa ortaya çıktığını, kadınların anlatılarından öğrenebiliyoruz. Bazen öğretmenler bu konuda kızlara öğüt vermektedir. "Dikiş ögretmenimiz çok konuşurdu bu konuda. Sağlam evlilik yapabilmek için acele etmemek lazım, eğitiminiz bitmeden böyle şeyler düşünmeyin derdi." ${ }^{\text {7 }}$ Kimi öğretmenler, kıların geleceklerini tehlikeye sokmamaları için kızları uyarabiliyordu. "Rehber ögretmen beni yüksek okula yönlendirdi. Biraz yakın bir arkadaşlık yapsam oradan uzaklaştırırdı beni. Bunu okumam için yaptı sanırım." "46 Bazı anlatılarda gelecekteki çocukların nasıl yetiştirilmesi gerektiği üzerinde durulmaktadır. "Kaç çocuk üzerinde durulmadı. Çocukların eğitimi nasıl olmalı, çocuklara nasıl bir gelecek hazırlanmall. Bunlar anlatıllyordu bize.” 47

Kadınlar genellikle Kız Enstitüleri'ni tek taraflı bir eğitim olarak tanımladılar. İsteyen bu okullara da gidebilirdi, o da gerekliydi; ama yeterli değildi. Tek taraflıydı, çünkü insanı her yönüyle yetiştirmiyordu. Kız Enstitülerinde sadece nakış, dikiş, çocuk bakımı ve yemek vard1. ${ }^{8}$ "Köy enstitüsü çok farklıydı. Sırf biçki-dikiş değil, biz her türlü şeyi yapıyorduk." "Onlara göre "kadınlık" eğitimi yeterli değildi, eğitim insanı her yönde geliştirmeliydi. “Kız Enstitüleri’nden çok farklıydl. Bize felsefi bir eğitim verildi." 48 "Köy Enstitüleri'nde yetişen insan bir bütün olarak yetişir." 49 Kadınlara hangisini okumak istediklerini sorduğumuzda, Köy Enstitüleri'nin her bakımdan Kız Enstitüleri’nden daha iyi bir eğitim anlayışına sahip olduğunu söylediler.

Karma eğitim suçlamaları, sanırım en fazla kadınları kızdırmaktadır. Anlatılar da, köylü kız çocuklarının o dönemin koşullarında okullara ne zorluklarla gidebileceği ve Köy Enstitüleri’nin yıkışının en fazla kız öğrencilere zarar verdiği yer almaktadır.

Onların istediği hocalar mı gönderildi bilemiyorum. Bu hoca mesela eğitim başı olarak kızlara bilhassa verilerek 40 kızlar diye ayırmasıyd. Hatta sinıflara bile ayırmaya kalktılarda ayırmadılar sonra. Zaten o zamandan kızların düşmanı oldular. Neden? Köydeki ă̆alar kızlar söz sahibi olmasın istediler. Kızlar kadındır, kadınlığını bilecek, kocasına yardım edecek ve onun arkasından gidecek. Eski adet ve gelenekleri birakmayacak. Kadın hürriyet sahibi olup da kendisini savunmayacak. Kocasına karşı kendisini savunmayacak. ${ }^{50}$

"Çevreden değil asıl bizi tenkit edenler baştakilerdi. Toprak ă̆alarıyd, meclistekilerdi. Köylerden biz hiçbir tepki görmedik. Köydekiler hep bize sarlldılar. Yani köylüler köy enstitülerine tepki göstermedi." 51

\footnotetext{
${ }^{6}$ Ankara, Ayşe Baysal, (21.03.2008 ve 07.04.2008).

${ }^{7}$ Ankara, Halise Apaydın, (26.02.2008 ve 04.03.2008)

${ }^{8}$ Ankara, Emine Biçer, (09.05.2008).

${ }^{9}$ Ankara, Meliha Sürücü, (25.04.2008).
} 
Enstitülü kızlara göre; Köy Enstitü’lerinin eğitim politikasının değiştirilme ve yıkılma sürecine girmesi, siyasi oyunların bir sonucudur. Bunun yanı sıra; okulların tasfiye edilmesinin en çok kadınlar üzerinde kurulmaya çalışılan bir baskı olduğunu dile getirdiler.

Kadınlara göre, Enstitüler'in kapatılmak istenmesinin nedenlerinden biri, tutucu iktidarın kızları eve gönderme çabasıdır. Kadınlar kızgındılar, kapatılma nedenleri arasında kızların eğitiminin kullanılması onları derinden etkiliyordu. “Köy Enstitüleri’ni kapattılar, ama böyle birşeyi ispat edemediler... Her klzlı erkekli çalışılan mesleklerde, okullarda olsun kız erkek arası ilişkiler olabilir... Ama bunlar kötü bir şekilde aktardılar suçladılar."10 Ayşe Baysal, 1950'den sonraki kız erkek öğrencileri ayırma politikalarını şu şekilde değerlendirmektedir. "Kızlara yazık oldu. Okula gidemediler. Enstitüleri ayırdıktan sonra sayıları iyice azaldı.. Uzaktaki okullara nasil gitsinler. "52

Kız-erkek arası ilişkilerin bir sorun olarak gösterilmesi ve bunun Enstitü’lere yönelik karalama politikasına dönüştürülmesi kadınların eleştirilerine yol açmıştır. Bu konuya yönelik en önemli eleştirileri, zaten köy yaşamında ve özellikle tarımda kadın ve erkeklerin birlikte çalıştıklarıdır. Bu suçlamaların köylüler tarafından değil de, iktidarda bulunanlar tarafından gerçekleştirilmesi ise; köylülerin, özellikle kadınların bilinçlenmesini ya da aydınlanmasını önleme girişimidir.

\section{Yok Sayma}

"Özellikle kız ögrencilerin hayatlarını anlatan bir kitap yok. Anılar yazılınca, Köy Enstitüleri’nin işleyiş tarzı ortaya çıkıyor. Özellikle kız ögrencilerin okuması için vurgular çok ama, kızlar zaten azdı okulda. Kızlarda yazı yazmak gibi bir amacı yoktu. Yapamadıkları için değil de, o firsatı bulamadıkları için ayrı bir zaman isteyen birşeydir. Ben evlendiğimiz zaman ikimizde okuyoruz. Ben bir kitap okuyorum eleştiriyorum. ... çok güzel dedi eleştiri yapıyorsun. Evlendik o yazar oldu. Çocuklar oldu. Okulun başöğretmeniyim o ilk yazıları yazdığım zaman. Evde yemeği ben yapacam, çamaşırı ben yapacam.. Ev kadınlı̆̆ını yapacaksın, okulda görevini yapacaksın. Çocuklarını büyüteceksin. Annen varsa ona bakacaksın, kadına öyle bir yük yükleniyor ki, o anda yazar olamaz. Benim görevim vard, yazacak hiç zamanım yoktu. "53

Enstitülü kızlar Köy Enstitüleri üzerine yazılanların, kadınların deneyimlerini aktarabilmesi açısından yeterli bulmamaktadırlar. ${ }^{54}$ Ama bunun yanı sıra, kız çocukların okumasının önemini anlatan yazılar da yok değildir. ${ }^{55}$ Enstitülerin karma eğitim uygulamasıyla kızların Enstitü’ye gelmelerinin yolunun açılması, kadınların yaşam hikayelerinin en önemli yerini oluşturmaktadır. Kadınlar tarafından Köy Enstitüleri deneyimlerinin neden yazılmadığı sorusu bazen bir pişmanlık, bazen de bir zamansızlık sorunu olarak dile getirilmektedir. Halise Apaydın hem yazmaya meraklı bir kadın, hem de Köy Enstitüleri üzerine yazıları da bulunmaktadır. Ama anlatısında da yer aldığı gibi, bazı nedenlerden dolayı yazma işine uzunca bir süre ara vermek zorunda kalmıştır. Halise Apaydın'ın söylediği gibi, yazma amaçları yoktu kadınların. Çünkü isteseler de zaten yazamıyorlardı. Çünkü evde yapılması gereken işler vardı. Bu yüzden yazı yazmak her zaman ikinci plana atılmak zorunda kalmıştı.

Perihan Gürler, bu dönemde yazı yazan kadınlardan birisidir. Eşiyle birlikte çıkardıkları "Köy ve Eğitim" dergisinde yazdıklarının dışında, "10 Kasım Çocuk Şiir'leri Antolojisi” derlemesi ve eşiyle hazırladıkları bir çok kitap yayınlamışlardır. Ama Köy Enstitüleri üzerine ya da kendi deyimleri hakkında yazmayı hiç düşünmemiştir. "Köy enstitüleri üzerine yazmadım, hiç çalışmayı düşünmedim, keşke o zamanlar bu konuda yazmayı düşünseydim". 56

Emine Biçer kadınların yazmamasını, onların uyanmamalarıyla açıklamaktadır. Kadınların bilinçlenmeleri demek, bir bakıma yazmaları demektir. Ama kadınlar uyanmadılar, yazamadılar. "Kadınlar zaten o zamanki hayatlarını anlatabilselerdi, biz zaten bu kadar çekmezdik. Şimdi bile anlatılanlar çok az, azınlıkta.. Kız ögrencilerin hayatını anlatan yazılar yok. O zaman bize açık açık sorulsaydı yada biz uyansaydık bir yazar olurduk, yazılar yazabilirdik.. Biz bunu yapmadık tembellik ettik herhalde. "57

Peki Enstitü, kadınlara geçmişten neler bırakmıştı. O günleri anlatırken yüzlerinde hep güçlü bir ifade vardı. Onlar dönemin en şanslı sayılabilecek kızlarıydı. Uyanmışlardı, köyü ve köylüyü uyandırmak için var gücüyle çalışan didinen kadınlardı onlar. Bu kadınlara göre kızların aydınlanması, köylü kadınları ve çocuklarının aydınlanmasıydı. "Okumuş kültürlü bir annenin çocuk yetiştirmesiyle okumamış bir kişinin çocuk yetiştirmesi bir olur mu. Atatürk bile her zaman bundan bahseder. Yani anaların okuması çok önemli. Yani bu işi Köy Enstitüleri fazlasıyla yapmıştı. Ben eğer okumasaydım, bu kültürü almasaydım, çocuklarıma bu alışkanlığ verebilir miydim. Ne kadar önemli çocukların okuması. Bak ben sizi yetiştirdim, siz çocuklarınızı yetiştirdiniz.

\footnotetext{
${ }^{10}$ Ankara, Halise Apaydın, (26.02.2008 ve 04.03.2008).
} 
Çocuklarınızda çocuklarınızı yetiştirecek. İki kişinin Köy Enstitüsü’nde yetişmesi kaç kuşağa kültür okuttu. Acaba enstitüler kapatılmasaydı Türkiye nerede olurdu. "58

Bu sözlerin haklılık payı vardı. Köy Enstitüleri’nin köy yaşamını dönüştürücü bir etkisi vardı. Ama Enstitülü kadınların hayatı için bu dönüştürme ve gelişme söylemi ne kadar geçerliydi. Kadınları, okumuş ev kadınlığından kurtarabilecek miydi? Yoksa hem ev kadınlığını hem de öğretmenlik görevlerini yapabilmek kadınlar için yetmez miydi! Artık kadınlar okuyabiliyordu, onlar gerçekten de özgürler miydi.?

Ev içi üretime dayalı bir eğitim politikası dışında, Enstitü ortamı kadınlara farklı güçlenme pratikleri de sunmaktadır. Halise Apaydın'ın aktardığı gibi, “Bu işler yürütülürken, kültür dersleri de devam ediyordu. Mezun olunca kültür, beceri, ögretmenlik formasyonu, onlara güven duygusu vermişti. "59 Kadınların sahip oldukları öğretmenlik mesleği, onları kamusal alana taşımıştı. Enstitü ortamı, kadınlara birey olma, sorumluluk alma ve düşüncelerini dile getirmek gibi özgürleştici bir deneyim kazandırdı. Kadınlar için Köy Enstitülü olmanın en önemli özelliği, haklarının bilince olmalarıydı. Onlar gerekli olduğu koşullarda haklarını aramayı ve savunmayı öğrenmişlerdi. Bir bakıma güçlenmişlerdi. "Enstitü kadınları güçlendirdi. Hangi Enstitü mezunuyla konuşursanız konuşun, bunları size söyleyecekler. Susmasını bilecek kız çocuğu yetiştirmediler orada.. Gelecekte Türkiye'nin ve kendinin hakkını savunabilecek kızlar yetiştirdiler'. ${ }^{\circ}$

\section{SONUÇ}

Enstitülü kızlar, hem hayata dair teorik bilgilerin yer aldığı hem de beden gücüyle deneyimledikleri yoğun bir eğitim politikasından geçirildiler. Pozitif ayrımcılık olarak değerlendirdikleri Enstitü hayatı, onlara farklı güçlenme pratikleri sunmasına rağmen; kızların iş eğitimi toplumsal cinsiyet rollerine göre belirlenmekteydi. Kızların ev içi rolleriyle bağlantı kurularak düzenlenen bu modern eğitim, Enstitülü kızlar tarafından köylere taşınarak köy kadınlarını yetiştirme ideali taşımaktaydı. Köy Enstitüleri’nin başlıca amaçlarından biri; cumhuriyet rejimi düşüncesini köylere ulaştırmak ve köy yaşamını modern kırsal bir yaşama dönüştürmektir. Buna bağlı olarak Enstitülü kadınların kırsal kalkınmadaki rolü ise, ailenin modernleşmesini sağlamaktı. 
1 Halise Apaydın'ın el yazısından. (2008)

${ }^{2}$ Köy enstitüleri hakkında yazılan kaynaklar genellikle, erkekler tarafından oluşturulmuştur. Yaptığımız araştırmada sadece, Pakize Türkoğlu'nun (Tonguç ve Enstitüler), Naciye Makal'(Bindim Tütün Küpesine)'ın ve Halise Apaydın (Sanat Eğitimi)'ın yazılarına ulaşılabilmiştir.

${ }^{3}$ Elif Ekin Akşit, Kızların Sessizliği Kız Enstitülerin Uzun Tarihi (İstanbul: İletişim Yayınları, 2005), 73-110.

${ }^{4}$ Fatmagül Berktay, Tarihin Cinsiyeti (İstanbul: Metis Yayınları, 2003), 93-106.

${ }^{5}$ Akșit, Kızların Sessizliği, 143-182.

${ }^{6}$ Akşit, Kızların Sessizliği, 143-182.

${ }^{7}$ Akşit, Klzların Sessizliği, 144.

${ }^{8}$ Engin Tonguç, Bir Eğitim Devrimcisi İsmail Hakkı Tonguç: Yaşamı, Öğretisi, Eylemi (İzmir: Yeni Kuşak Köy Enstitülüler Derneği Yayın, 2007), 223.

${ }^{9}$ Ankara, Ayșe Baysal, (21.03.2008 ve 07.04.2008).

${ }^{10}$ Ankara, Halise Apaydın, (26.02.2008 ve 04.03.2008).

${ }^{11}$ Ankara, Ayşe Baysal, (21.03.2008 ve 07.04.2008).

${ }^{12}$ Ankara, Perihan Gürler, (14.03.2008) .

${ }^{13}$ Ankara, Halise Apaydın, (26.02.2008 ve 04.03.2008).

${ }^{14}$ Ankara, Ayşe Baysal, (21.03.2008 ve 07.04.2008).

${ }^{15}$ Ankara, Emine Biçer, (09.05.2008).

${ }^{16}$ Ankara, Emine Biçer, (09.05.2008).

${ }^{17}$ Ankara, Halise Apaydın, (26.02.2008 ve 04.03.2008).

${ }^{18}$ Ankara, Meliha Sürücü, (25.04.2008); Ayşe Baysal, (21.03.2008 ve 07.04.2008).

${ }^{19}$ Köy Enstitüleri Programı, 233-240.

${ }^{20}$ Köy Enstitüleri Programı, 112.

${ }^{21}$ Ankara, Meliha Sürücü, (25.04.2008).

${ }^{22}$ Ankara, Halise Apaydın, (26.02.2008 ve 04.03.2008).

${ }^{23}$ Ankara, Perihan Gürler, (14.03.2008).

${ }^{24}$ Ankara, Emine Biçer, (09.05.2008); Ankara, Meliha Sürücü, (25.04.2008).

${ }^{25}$ Ankara, Meliha Sürücü, (25.04.2008).

${ }^{26}$ Krizma, sert yapılı topraklarda köklerin derine gidebilmesi için toprağın 40-50 cm. derinlikte işlenmesidir.

${ }^{27}$ Ankara, Emine Biçer, (09.05.2008).

${ }^{28}$ Ankara, Halise Apaydın, (26.02.2008 ve 04.03.2008)

${ }^{29}$ Ankara, Ayşe Baysal, (21.03.2008 ve 07.04.2008).

${ }^{30}$ Köy Enstitüleri Programı, 225.

${ }^{31}$ Ankara, Perihan Gürler, (14.03.2008).

${ }^{32}$ Yüksek Köy Enstitüsü 1942-43 öğretim yılında hem köy enstitülerine öğretmen, hem ilköğretime öğretmen, yönetici ve denetim elemanı yetiştirmek, hem de köy araştırmalarına merkez olmak üzere kuruldular (Altunya, 2005, s.21).

33"Talebeyi ve köylü halkı asrın icaplarına göre yetiștirme ve yükseltmede, kadın erkek farkı gözetmemelidir."

${ }^{34}$ Ankara, Emine Biçer, (09.05.2008); Ankara, Halise Apaydın, (26.02.2008 ve 04.03.2008); Ankara, Meliha Sürücü, (25.04.2008).

${ }^{35}$ Ankara, Meliha Sürücü, (25.04.2008).

${ }^{36}$ Ankara, Perihan Gürler, (14.03.2008).

${ }^{37}$ Ankara, Halise Apaydın, (26.02.2008 ve 04.03.2008).

${ }^{38}$ Ankara, Halise Apaydın, (26.02.2008 ve 04.03.2008).

${ }^{39}$ Ankara, Meliha Sürücü, (25.04.2008).

${ }^{40}$ Ankara, Halise Apaydın, (26.02.2008 ve 04.03.2008).

${ }^{41}$ Ankara, Emine Biçer, (09.05.2008).

${ }^{42}$ Ankara, Halise Apaydın, (26.02.2008 ve 04.03.2008).

${ }^{43}$ Ankara, Perihan Gürler, (14.03.2008).

${ }^{44}$ Ankara, Emine Biçer, (09.05.2008).

${ }^{45}$ Ankara, Ayşe Baysal, (21.03.2008 ve 07.04.2008).

${ }^{46}$ Ankara, Ayşe Baysal, (21.03.2008 ve 07.04.2008).

${ }^{47}$ Ankara, Emine Biçer, (09.05.2008).

${ }^{48}$ Ankara, Ayşe Baysal, (21.03.2008 ve 07.04.2008).

${ }^{49}$ Ankara, Halise Apaydın, (26.02.2008 ve 04.03.2008).

${ }^{50}$ Ankara, Emine Biçer, (09.05.2008).

${ }^{51}$ Ankara, Perihan Gürler, (14.03.2008).

${ }^{52}$ Ankara, Ayşe Baysal, (21.03.2008 ve 07.04.2008).

${ }^{53}$ Ankara, Halise Apaydın, (26.02.2008 ve 04.03.2008).

${ }^{54}$ Ankara, Perihan Gürler, (14.03.2008); Ankara, Emine Biçer, (09.05.2008); Ankara, Halise Apaydın, (26.02.2008 ve 04.03.2008).

${ }^{55}$ Ankara, Halise Apaydın, (26.02.2008 ve 04.03.2008); Ankara, Ayşe Baysal, (21.03.2008 ve 07.04.2008).

${ }^{56}$ Ankara, Perihan Gürler, (14.03.2008).

${ }^{57}$ Ankara, Emine Biçer, (09.05.2008).

${ }^{58}$ Ankara, Perihan Gürler, (14.03.2008).

${ }^{59}$ Halise Apaydın'ın el yazısından. (tarihsiz).

${ }^{60}$ Ankara, Emine Biçer, (09.05.2008). 